\title{
Outcomes of Primary Percutaneous Coronary Intervention in Acute Myocardial Infarction at Tehran Heart Center
}

\author{
Mohammad Alidoosti Mojtaba Salarifar Alimohammad Hajizeinali \\ Seyed Ebrahim Kassaian Davood Kasemisaleh Hamidreza Goodarzynejad
}

Tehran Heart Center, Tehran University of Medical Sciences, Tehran, Iran

\begin{abstract}
Key Words
Primary percutaneous coronary intervention · ST-segment myocardial infarction - Major adverse cardiac events
\end{abstract}

\begin{abstract}
Objective: To describe our experience of primary angioplasty in ST-segment elevation myocardial infarction. Subjects and Methods: During a period of 2 years (April 2003 to May 2005), 83 high-risk patients presenting with acute ST-segment elevation myocardial infarction underwent primary angioplasty subject to availability of balloon dilation within 90 min of admission. In total, 73 stents were implanted; 69 were bare metal stents, while the remaining 4 were paclitaxel-eluting stents. Of the 83 patients, 8 presented with cardiogenic shock. Follow-up was for a period of 9 months. All angiographic, in-hospital and clinical outcomes were recorded on a database. Results: The procedure was successful in 79 of the 83 patients (95\%) and unsuccessful in 4 (5\%). Of these 4 patients, 3 died and 1 was treated medically. In 65 patients with zero perfusion, angioplasty was successful in 61 (93.8\%), while it was completely successful (100\%) in the remaining 18 patients with thrombolysis in myocardial infarction grade 3 perfusion. Vessel patency was achieved in 95\% with thrombolysis in myocardial infarction grade 3 flow present in $93 \%$. A total of 7 (8.5\%) patients died while in the hospital. Of the 8 with initial cardiogenic shock on presentation, 4 (50\%) died in the hospital and of the remaining 4, 1 was lost at 9-month follow-up. In-hospital reocclusion and
\end{abstract}

reinfarction did not occur in any patient. Conclusion: The results suggest that primary angioplasty is logistically feasible in our center with good clinical outcomes.

Copyright $\odot 2007$ S. Karger AG, Basel

\section{Introduction}

Reperfusion therapy is the cornerstone in treatment of patients with acute ST-segment elevation myocardial infarction (STSEMI). Primary angioplasty without antecedent thrombolytic therapy, an effective means of achieving coronary reperfusion in patients presenting with an acute STSEMI, has been described by Meyer et al. [1] and Hartzler et al. [2]. For over 20 years, primary percutaneous coronary intervention (primary PCI) has been advocated for treatment of STSEMI. An updated comprehensive meta-analysis of 23 multicenter randomized trials indicates that primary PCI is superior to thrombolysis, resulting in a markedly lower occurrence of shortterm major adverse cardiac events (MACEs), including death, in individuals with STSEMI. Moreover, these favorable results were sustained during long-term followup [3]. Primary PCI has been associated with an improved clinical outcome compared to thrombolytic therapy, irrespective of the type of thrombolytic regimen used. Furthermore, most STSEMI patients are not candidates for fibrinolytic therapy, either because they have bleeding risks or shock, or do not have diagnostic electrocardio-

Mohammad Alidoosti

Tehran Heart Center

Jalal Al-Ahmad and North Kargar Cross

Tehran (Iran)

Tel. +98 218802 9245, Fax +98 218802 9256, E-Mail alidostm@sina.tums.ac.ir 
grams $[4,5]$. The invasive approach can be applied to almost all of these patients at interventional centers. In addition, primary angioplasty may be more cost-effective than fibrinolytic therapy $[6,7]$. Therefore, primary PCI is widely regarded as the reperfusion strategy of choice in STSEMI if it can be performed within $2 \mathrm{~h}$ of presentation to the hospital (door-to-balloon time $<2 \mathrm{~h}$ ).

A major disadvantage of primary PCI in comparison with thrombolysis has been the limited access resulting in a time delay until treatment. Other limitations of primary angioplasty include critical dependence on operator experience and longer time to treatment [8]. Since 2003, facilities have been provided and protocols established at Tehran Heart Center to regularly perform primary angioplasty in a timely fashion (door-to-balloon time $<90 \mathrm{~min}$ ). Therefore, the objective of this study was to report the initial and long-term outcomes of patients who underwent primary PCI at Tehran Heart Center, a large institution performing more than 1,500 elective angioplasties per year.

\section{Subjects and Methods}

\section{Study Population and Protocol}

The study was conducted from April 2003 to May 2005. A total of 512 patients with STSEMI were admitted during the study period. Inclusion criteria were the presence of symptoms consistent with acute myocardial infarction (AMI) for at least $30 \mathrm{~min}$ but less than $12 \mathrm{~h}$, the presence of ST-segment elevation in at least two contiguous leads or left bundle-branch block and the feasibility of performing balloon dilation within 90 min of admission ('doorto-balloon time' $<90 \mathrm{~min}$ ). The clinical exclusion criteria were: inability to provide informed consent; pulseless femoral arteries; nonischemic heart disease and noncardiac disease associated with a life expectancy of less than 12 months; females of childbearing age, unless the result of a recent pregnancy test was negative; those with known contraindications to aspirin, heparin, ticlopidine or clopidogrel (Plavix).

Angiographic criteria for exclusion from PCI were stenosis of the left main coronary artery of more than $70 \%$ (not protected by collateral circulation), presence of critical three-vessel disease (with $\geq 70 \%$ stenosis in each vessel) or morphologic features of the lesion known to indicate high risk [9]. Bypass surgery was recommended for these high-risk patients. Patients were also excluded if they seemed unlikely to benefit from PCI because the infarct-related vessels were small, there was stenosis of less than $70 \%$ with thrombolysis in myocardial infarction (TIMI)-3 flow, or the infarct-related vessel could not be identified. Most exclusions, however, were due to unavailability of the service in a timely fashion in terms of operator and laboratory requirements, since primary PCI has not yet become the 'default' treatment during off-hours, and currently the program operates exclusively during the day, on weekdays for patients who arrive during the time when the program is being offered.
Of a total of 512 patients, 429 were excluded for the following reasons: 316 patients received thrombolytic therapy due to unavailability of the catheterization laboratory during off hours; in 101 patients more than $12 \mathrm{~h}$ had elapsed from the onset of chest pain, and in 12 patients coronary anatomy was not suitable for angioplasty or the involved vessel supplied a small territory of myocardium considered for medical treatment. The remaining 83 patients provided written informed consent and in the case of the patient's inability, informed consent was obtained from the relatives. Nineteen patients $(23 \%)$ were $>65$ years of age and 8 presented with cardiogenic shock. The mean duration of chest pain before arriving at the Emergency Department was 204 min. Anterior and inferior infarctions were noted in 55 and 28 patients, respectively. Seventy patients $(84 \%)$ had single vessel disease with a mean age of $51.54 \pm 14.43$ vs. $57.08 \pm 9.60$ years in patients with multivessel disease $(\mathrm{p}=0.55)$. In two thirds of the cases, the target vessel was left anterior descending (LAD). Additionally, in 7 patients, a second critically stenotic vessel was treated - five diagonals, one LAD, and one left circumflex. In total, 73 stents were implanted; 69 (95\%) bare metal and 4 paclitaxel-eluting stents. The stent diameter was $3.08 \pm 0.38 \mathrm{~mm}$ while the length was $19.96 \pm 5.79 \mathrm{~mm}$.

\section{Catheterization Procedure and Medications}

Before undergoing catheterization, patients received $325 \mathrm{mg}$ of chewable aspirin, $300 \mathrm{mg}$ of Plavix orally, and a 5,000-unit bolus of heparin. Patients immediately underwent diagnostic catheterization. In patients with TIMI grade 3 flow in an infarct-related vessel upon first angiography, percutaneous intervention was performed in the case of a residual critical stenosis $(\geq 70 \%)$ accompanied with signs and symptoms of ongoing or remittent ischemia, high-risk lesion morphology for reocclusion and/or presence of a large myocardial territory in jeopardy. If the patient was eligible for PCI, additional heparin was administered $(5,000$ 10,000 units), and angioplasty procedure was performed using standard techniques. After the intervention, patients received 325 $\mathrm{mg}$ of aspirin daily, as well as beta-blockers and angiotensin-converting enzyme inhibitors, provided that these agents were not contraindicated. Sixty-nine (69) patients who received bare metal stents were given $75 \mathrm{mg}$ of Plavix per day or $250 \mathrm{mg}$ of ticlopidine twice daily for 4 weeks, while 4 patients who received drug-eluting stents continued to take Plavix or ticlopidine for 6-12 months. Follow-up visits were scheduled at 1, 4, and 9 months.

\section{Data Collection and Management}

The following data were collected: baseline demographics, medical history, medications, procedures, complications, and clinical events. Follow-up was performed during office visits to physicians or obtained by means of telephone interview. Data from completed collection forms were entered into an Access database. All angiographic films were reviewed for accuracy by a single cardiologist who was unaware of patients' clinical outcomes. The left ventricular ejection fraction and regional wall motion were determined using either echocardiography or contrast ventriculography during the procedure.

The primary end point was clinical success. Angiographic success was defined as post-procedure TIMI flow grade more than 2 and a residual stenosis less than $50 \%$. MACEs were defined as the total number of deaths from any causes, reinfarction, and repeated intervention or revascularization of the target vessel as 
Table 1. Baseline characteristics of patients

\begin{tabular}{lc}
\hline Mean age, years & $55 \pm 12$ \\
Age range, years & $21-80$ \\
Sex, M/F & $64 / 19(77 / 23)$ \\
Age $\geq 65$ years & $19(23)$ \\
MI location & \\
$\quad$ Anterior & $55(66)$ \\
$\quad$ Inferior & $28(34)$ \\
Ischemic time & \\
$\quad$ Mean, min & $204 \pm 144$ \\
$\quad$ Range, min & $60-720$ \\
$\quad \leq 2$ h & $35(42)$ \\
$\quad 2-4$ h & $25(30)$ \\
$\quad 4-6$ h & $13(16)$ \\
$\quad>6$ h & $10(12)$ \\
Cardiogenic shock & $8(10)$ \\
Prior CABG & 0 \\
Prior PCI & $7(8)$ \\
Diabetes mellitus & $16(19)$ \\
Hypertension & $31(37)$ \\
Hypercholesterolemia & $32(38)$ \\
Previous stroke & 0 \\
Previous MI & $12(14)$ \\
Ejection fraction & $45 \pm 12$ \\
EF range, \% & $20-75$ \\
\hline
\end{tabular}

Figures in parentheses indicate percentages.

a result of ischemia. Reinfarction was defined as recurrent symptoms of ischemia with new electrocardiographic changes and/or a rise in $\mathrm{CK}-\mathrm{MB}$ more than twice the normal limits. Revascularization of the target vessel was considered to have been prompted by ischemia if there was evidence of ischemia during functional testing or angina. Clinical success was defined as successful procedure in the absence of in-hospital MACEs.

Statistical analysis was performed with the SPSS software v11.5 statistical package. Continuous data were expressed as mean \pm SD and categorical data as percentage. Statistical analyses were completed on the categorical variables using a $\chi^{2}$ or a Fisher exact test as appropriate. A p value of less than 0.05 was judged statistically significant. Relative risks were calculated with $95 \%$ confidence intervals. Differences between means were assessed with the two-tailed Student's t test and differences in outcomes in shock and non-shock patients were computed using the MantelHaenszel test.

\section{Results}

Patients' demographics and angiographic records are listed in tables 1 and 2 . The angioplasty procedure was successful in 79 (95\%) of cases, but unsuccessful in 4 (5\%). In patients with TIMI grade 0 perfusion (occluded
Table 2. Basic angiographic characteristics

\begin{tabular}{|c|c|c|}
\hline & \multicolumn{2}{|c|}{ Patients } \\
\hline & $\mathrm{n}$ & $\%$ \\
\hline Multi vessel disease & 13 & 16 \\
\hline \multicolumn{3}{|l|}{ Infarct-related artery } \\
\hline Left main & 1 & 1 \\
\hline LAD & 50 & 60 \\
\hline LCX & 5 & 6 \\
\hline RCA & 27 & 32 \\
\hline \multicolumn{3}{|c|}{ TIMI grade (perfusion) before procedure } \\
\hline 0 & 65 & 78 \\
\hline 1 & 8 & 10 \\
\hline 2 & 5 & 6 \\
\hline 3 & 5 & 6 \\
\hline \multicolumn{3}{|c|}{ TIMI grade (perfusion) after procedure } \\
\hline $0-1$ & 1 & 1 \\
\hline 2 & 7 & 8 \\
\hline 3 & 75 & 90 \\
\hline \multicolumn{3}{|l|}{ Lesion characteristics } \\
\hline Ostial & 6 & 7 \\
\hline Proximal & 25 & 30 \\
\hline Long $(>10,<20 \mathrm{~mm})$ & 44 & 53 \\
\hline Diffuse $(\geq 20 \mathrm{~mm})$ & 22 & 26 \\
\hline Complex lesions $^{1}$ & 79 & 95 \\
\hline $\mathrm{EF} \leq 40 \%$ & 16 & 19 \\
\hline
\end{tabular}

LCX = Left circumflex; RCA = right coronary artery; EF = ejection fraction.

${ }^{1}$ American Heart Association classification/lesion type B2 and C.

infarct-related artery), the success rate was $93.8 \%$ (61 of 65 ) compared to $100 \%$ (18 of 18 ) in patients with TIMI grade 1 or more perfusion. The angioplasty success rates in patients with single- versus multivessel disease were 95 and $92 \%$, respectively. Of the 4 patients with failed angioplasty, 3 died and 1 was treated medically; no one underwent urgent coronary artery bypass surgery. The mortality rate was relatively low (8.4\%; table 3$)$. In 8 patients who presented with cardiogenic shock, the mortality was $50 \%$; in the 75 patients without shock, it was 4\%. In-hospital reocclusion and reinfarction did not occur in any patient. There were also no occurrences of stroke or transient ischemic attack. Mechanical support with an intraaortic balloon pump was used only in 7 patients $(6 \%) ; 5$ were in the (63\%) and 2 in the non-shock group (3\%).

At 9 months, the cumulative incidence of the primary end point - a composite of death, reinfarction, revascularization, or disabling stroke - was 75 and 5.3\% in patients who presented with and without shock, respective- 
Table 3. In-hospital and late outcomes in patients undergoing primary angioplasty

\begin{tabular}{lllll}
\hline Outcome & $\begin{array}{l}\text { Total } \\
(\mathrm{n}=83)\end{array}$ & $\begin{array}{l}\text { Initial cardio- } \\
\text { genic shock } \\
(\mathrm{n}=8)\end{array}$ & $\begin{array}{l}\text { Without } \\
\text { shock } \\
(\mathrm{n}=75)\end{array}$ & $\begin{array}{l}\mathrm{p} \\
\text { value }\end{array}$ \\
\hline $\begin{array}{l}\text { In-hospital event rates } \\
\quad \begin{array}{l}\text { Death } \\
\text { Reinfarction }\end{array}\end{array}$ & $7(8.4)$ & $4(50)$ & $3(4)$ & 0.001 \\
$\begin{array}{l}\text { TVR } \\
\text { Stroke or TIA }\end{array}$ & - & - & - & - \\
$\begin{array}{l}\text { Composite end point } \\
\text { At 9-month follow-up }\end{array}$ & - & - & - & - \\
$\quad \begin{array}{l}\text { Death } \\
\text { Reinfarction }\end{array}$ & $7(8.4)$ & $4(50)$ & $3(4)$ & 0.001 \\
$\begin{array}{l}\text { TVR } \\
\text { Stroke or TIA }\end{array}$ & $1(1.2)$ & $1(12.5)$ & - & $<0.001$ \\
$\begin{array}{l}\text { Composite end point } \\
\text { (cumulative) }\end{array}$ & $2(2.4)$ & $1(12.5)$ & $1(1.3)$ & 0.007 \\
\hline
\end{tabular}

TVR $=$ Target vessel revascularization; TIA $=$ transient ischemic attack. Figures in parentheses indicate percentages. ly $(\mathrm{p}=0.007)$. Despite a 50\% in-hospital mortality rate, only 1 fatality occurred within 9 months after hospital discharge among patients with cardiogenic shock.

\section{Discussion}

The success rate of angioplasty in this study (95\%) was similar to that in other series $[10,11]$; however, in our study, no patient underwent emergency bypass surgery following unsuccessful PCI.

\section{Reperfusion}

Coronary patency, defined as the restoration of normal blood flow in the infarct-related vessel, preserves myocardial tissue and results in improved survival. With primary angioplasty, 95\% of infarct vessels were successfully reperfused. In contrast, intravenous streptokinase therapy without further intervention leads to an infarct vessel patency rate from 41 to $55 \%[12,13]$. Although tissue plasminogen activator [12] and various combinations of intravenous thrombolytic agents [14] improve this rate of recanalization, there appears to be a 'pharmacologic intervention plateau' at approximately $75 \%$ with respect to acute infarct vessel patency [15].

One of the main findings of the present study is that among patients with STSEMI undergoing primary angioplasty, poor myocardial perfusion is a major explanation of the poor outcome observed in patients with shock at presentation. Despite the significant improvement in survival of patients undergoing primary angioplasty, the mortality rate in patients with cardiogenic shock at presentation remains disappointingly high [16].

In this series, primary angioplasty for AMI was highly effective in reestablishing infarct-vessel patency resulting in low in-hospital and long-term morbidity and mortality. These findings are particularly notable because in spite of using intra-aortic balloon pump most of the mortalities were among patients presenting with shock to the catheterization laboratory.

\section{Mortality}

The in-hospital mortality of $8.4 \%$ in this series of patients is similar to the mean in-hospital mortality from other more selected series using primary angioplasty for AMI [15]. This compares favorably with the $11-20 \%$ mortality rate in historical control subjects treated with traditional conservative therapy [17]. The in-hospital death rates for patients with successful versus failed angioplasty were 5 and $75 \%$. This finding, corroborated by previous reports $[18,19]$, suggests that the ability to reopen the infarct artery exerts a powerful influence on subsequent mortality.

In studies assessing intravenous thrombolytic therapy with or without adjunctive coronary angioplasty, where rigid selection criteria were used to exclude patients aged $>75$ years, those with prior bypass surgery or cardiogenic shock, and those presenting later than $4 \mathrm{~h}$ after the on- 
set of symptoms, a very low hospital mortality rate (4-7\%) has been reported $[20,21]$.

The excellent long-term outcome seen in this series has also been noted in previous trials using angioplasty for AMI. In a meta-analysis from Keeley et al. [3], 23 randomized trials showed that follow-up mortality for hospital survivors was near $10 \%$. The long-term benefits of direct coronary angioplasty may be the result of many factors, including early myocardial salvage, limitation of ventricular dilatation after infarction [22] or prevention of ventricular dysrhythmias [23].

The main limitation of the study was that while multicenter primary angioplasty trials have included many thousands of acute STSEMI patients undergoing reperfusion therapy, our study included only 83 patients from a single center. However, this center is one of the pioneers in the performance of regular primary PCI in Iran. Dur- ing the study, abciximab was not used; this additional therapeutic option may have a positive impact on clinical outcome [24].

\section{Conclusion}

The outcomes indicate that immediate coronary reperfusion with primary angioplasty can be performed safely and effectively with excellent outcomes in a large high-risk population of patients with acute STSEMI, when appropriate. To keep pace with other modern countries in the routine application of this strategy in patients with STSEMI, more hospitals in Iran should be equipped with facilities for coronary angioplasty, a cardiac catheterization team and an on-call invasive cardiologist experienced in primary angioplasty.

\section{References}

1 Meyer J, Merx W, Dorr R, Lambertz H, Bethge C, Effert S: Successful treatment of acute myocardial infarction shock by combined percutaneous transluminal coronary recanalization and percutaneous transluminal coronary angioplasty. Am Heart J 1982; 103:132-113.

-2 Hartzler GO, Rutherford BD, McConahay DR, Johnson WL Jr, McCallister BD, Gura GM Jr, Conn RC, Crockett JE: Percutaneous transluminal coronary angioplasty with and without thrombolytic therapy for treatment of acute myocardial infarction. Am Heart J 1983;106:965-973.

$>3$ Keeley EC, Boura JA, Grines CL: Primary angioplasty versus intravenous thrombolytic therapy for acute myocardial infarction: a quantitative review of 23 randomised trials. Lancet 2003;361:13-20.

4 The TIMI Study Group: Effects of tissue plasminogen activator and a comparison of early invasive and conservative strategies in unstable angina and non-Q-wave myocardial infarction: results of the TIMI IIIB Trial. Thrombolysis in Myocardial Ischemia. Circulation 1994;89:1545-1556.

$\checkmark 5$ Rogers WJ, Bowlby LJ, Chandra NC, French WJ, Gore JM, Lambrew CT, Rubison RM, Tiefenbrunn AJ, Weaver WD: Treatment of myocardial infarction in the United States (1990 to 1993). Observations from the National Registry of Myocardial Infarction. Circulation 1994;90:2103-2114
-6 Reeder GS, Bailey KR, Gersh BJ, Holmes DR Jr, Christianson J, Gibbons RJ: Cost comparison of immediate angioplasty versus thrombolysis followed by conservative therapy for acute myocardial infarction: a randomized prospective trial. Mayo Coronary Care Unit and Catheterization Laboratory Groups. Mayo Clin Proc 1994;69:5-12.

7 Stone GW, Grines CL, Rothbaum D, Browne KF, O'Keefe J, Overlie PA, Donohue BC, Chelliah N, Vlietstra R, Catlin T, O’Neill WW: Analysis of the relative costs and effectiveness of primary angioplasty compared to tissue plasminogen activator: the Primary Angioplasty in Myocardial Infarction (PAMI) trial. J Am Coll Cardiol 1997;901907.

8 Armstrong PW, Collen D: Fibrinolysis for acute myocardial infarction: current status and new horizons for pharmacological reperfusion, part 2. Circulation 2001;103: 2987-2992.

>9 Guidelines for percutaneous transluminal coronary angioplasty: a report of the American College of Cardiology/American Heart Association Task Force on Assessment of Diagnostic and Therapeutic Cardiovascular Procedures (Subcommittee on Percutaneous Transluminal Coronary Angioplasty). J Am Coll Cardiol 1988;12:529-545.

$\checkmark 10$ O’Keefe JH Jr, Rutherford BD, McConahay DR, Ligon RW, Johnson WL Jr, Giorgi LV, Crockett JE, McCallister BD, Conn RD, Gura GM Jr: Early and late results of coronary angioplasty without antecedent thrombolytic therapy for acute myocardial infarction. Am J Cardiol 1989;64:1221-1230.
11 Rothbaum DA, Linnemeier TJ, Landin RJ, Steinmetz EF, Hillis JS, Hallam CC, Noble RJ, See MR: Emergency percutaneous transluminal coronary angioplasty in acute myocardial infarction: a 3 year experience. J Am Coll Cardiol 1987; 10:264-272.

12 Chesebro JH, Knatterud G, Roberts R, Borer J, Cohen LS, Dalen J, Dodge HT, Francis CK, Hillis D, Ludbrook P: Thrombolysis in Myocardial Infarction (TIMI) trial. Phase 1: a comparison between intravenous tissue plasminogen activator and intravenous streptokinase. Clinical findings through hospital discharge. Circulation 1987;76:142154.

13 Verstraete M, Bernard R, Bory M, Brower RW, Collen D, de Bono DP, Erbel R, Huhmann W, Lennane RJ, Lubsen J: Randomized trial of intravenous recombinant tissue-type plasminogen activator versus intravenous streptokinase in acute myocardial infarction. Report from the European Cooperative Study Group. Lancet 1985;1:842-847.

14 Collen D, Van de Werf F: Coronary arterial thrombolysis with low-dose synergistic combinations of recombinant tissue-type plasminogen activator [t-PA] and recombinant single-chain urokinase-type plasminogen activator (rscu-PA) for acute myocardial infarction. Am J Cardiol 1987;60:431-434.

15 Topol EJ: Coronary angioplasty for acute myocardial infarction. Ann Intern Med 1988;109:970-980. 
16 Zeymer U, Vogt A, Zahn R, Weber MA, Tebbe U, Gottwik M, Bonzel T, Senges J, Neuhaus KL; The Arbeitsgemeinschaft Leitende Kardiologische Krankenhausarzte (ALKK): Predictors of in-hospital mortality in 1333 patients with acute myocardial infarction complicated by cardiogenic shock treated with primary percutaneous coronary intervention (PCI): results of the primary PCI registry of the Arbeitsgemeinschaft Leitende Kardiologische Krankenhausärzte (ALKK). Eur Heart J 2004;25:322-328.

$\checkmark 17$ The Multicenter Postinfarction Research Group: Risk stratification and survival after myocardial infarction. N Engl J Med 1983; 309:331-336.

18 Stack RS, Califf RM, Hinohara T, Phillips HR, Pryor DB, Simonton CA, Carlson EB, Morris KG, Behar VS, Kong Y: Survival and cardiac event rates in the first year after emergency coronary angioplasty for acute myocardial infarction. J Am Coll Cardiol 1988;11:1141-1149.
19 Ellis SG, O’Neill WW, Bates ER, Walton JA Jr, Nabel EG, Werns SW, Topol EJ: Implications for patient triage from survival and left ventricular functional recovery analyses in 500 consecutive patients treated with coronary angioplasty for acute myocardial infarction. J Am Coll Cardiol 1989;13:12511259.

20 Topol EJ, Califf RM, George BS, Kereiakes DJ, Abbottsmith CW, Candela RJ, Lee KL, Pitt B, Stack RS, O’Neill WW: A randomized trial of immediate versus delayed elective angioplasty after intravenous tissue plasminogen activator in acute myocardial infarction. N Engl J Med 1987;317:581-588.

21 The TIMI Study Group: Comparison of invasive and conservative strategies after treatment with intravenous tissue plasminogen activator in acute myocardial infarction. $\mathrm{N}$ Engl J Med 1989;320:618-627.
22 Warren SE, Royal HD, Markis JE, Grossman W, McKay RG: Time course of left ventricular dilation after myocardial infarction: influence of infarct-related artery and success of coronary thrombolysis. J Am Coll Cardiol 1988;11:12-19.

23 Kersschot IE, Brugada P, Ramentol M, Zehender M, Waldecker B, Stevenson WG, Geibel A, De Zwaan C, Wellens HJ: Effects of early reperfusion in acute myocardial infarction on arrhythmias induced by programmed stimulation. a prospective randomized study. J Am Coll Cardiol 1986;7: 1234-1242.

24 Neumann FJ, Blasini R, Schmitt C, Alt E, Dirschinger J, Gawaz M, Kastrati A, Schomig A: Effect of glycoprotein ub/ uta receptor blockade on recovery of coronary of coronary flow and left ventricular function after the placement of coronary-artery stents in acute myocardial infarction. Circulation 1998;98:2695-701. 